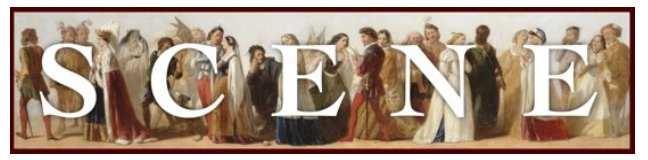

\title{
Politics and People at the Bridge Theatre's Julius Caesar
}

\author{
by Erin E. Kelly. Published in 2018 Issue 1. \\ For the production: Julius Caesar (2018, Bridge Theatre). Performance attended: 2018-04-08 (matinee). See \\ production details at the end of the review.
}

ANYONE WHO HAS BEEN TO A POLITICAL RALLY FOR A NATIONAL FIGURE IN THE PAST FEW YEARS WOULD HAVE recognized at least one of the songs a rock band played at high volume as the audience settled into seats or gathered on the floor of the Bridge Theatre performance space. "Roar" became an anthem for Hillary Clinton, with Katy Perry performing it at the Democratic National Convention.

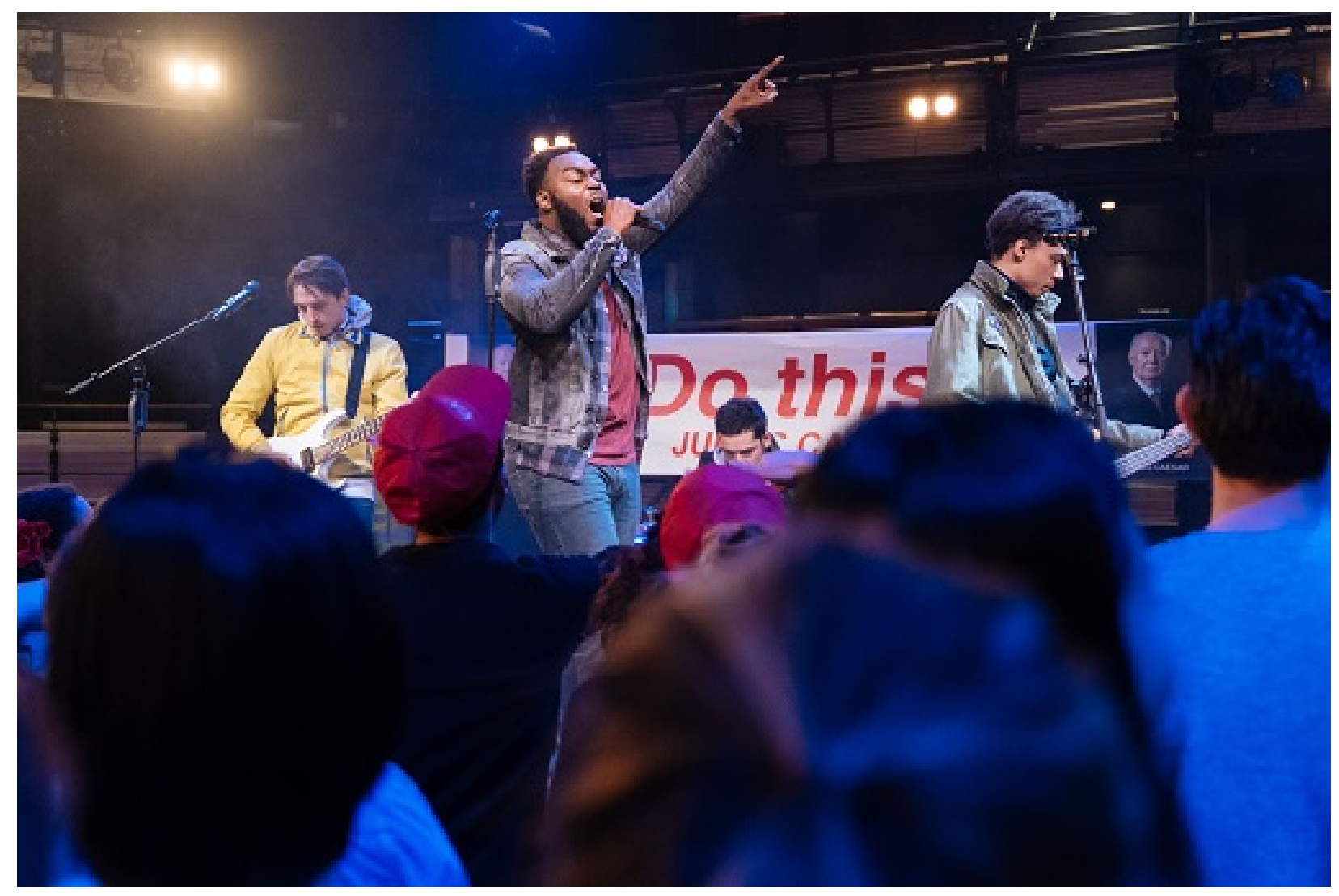

Figure 1. Preshow. Bridge Theatre. Production shots by Manuel Harlan.

Mike Huckabee's use of "Eye of the Tiger" got him sued by a member of Survivor horrified by the politician's support of a state official who refused to grant marriage licenses to same-sex couples. Similarly, Twisted Sister asked that Donald Trump stop using their anthem "We're Not Gonna Take It" at his campaign rallies. And Jack White's thumping "Seven Nation Army" became the 
music behind a chant of "Oh, Jeremy Corbyn" among that Labour leader's supporters. Furthering the impression that contemporary politics would be the focus of this production, vendors in the lobby and on the theatre floor hawked red baseball caps, albeit ones emblazoned with the word "CAESAR" instead of the phrase "Make America Great Again." But rather than presenting Julius Caesar as a Donald Trump figure-as did summer 2017's Shakespeare in the Park production of the play-the Bridge Theatre production took on a wider target: the dangers of too strongly linking any set of political principles to an individual personality-dangers that this very smart, sometimes thrilling production showed to be equally problematic for supporters and opponents of a charismatic leader.

The promenade staging of Julius Caesar in the Bridge Theatre's flexible space rightly received a lot of attention in newspaper and online reviews. The large central floor, a black square where audience members could stand and actors could perform, with seating for additional spectators on three tiers of galleries on all four sides combined the neutrality of a black box theatre with the intimacies of both theatrein-the-round and the "groundling" experience at the new Globe. As platforms rose up from the floor to form small or large, separate or conjoined playing spaces, the room presented scenes as varied as a private study, the floor of the senate, a living room, and a battlefield. The standing audience members, guided by both uniformed staff members and performers

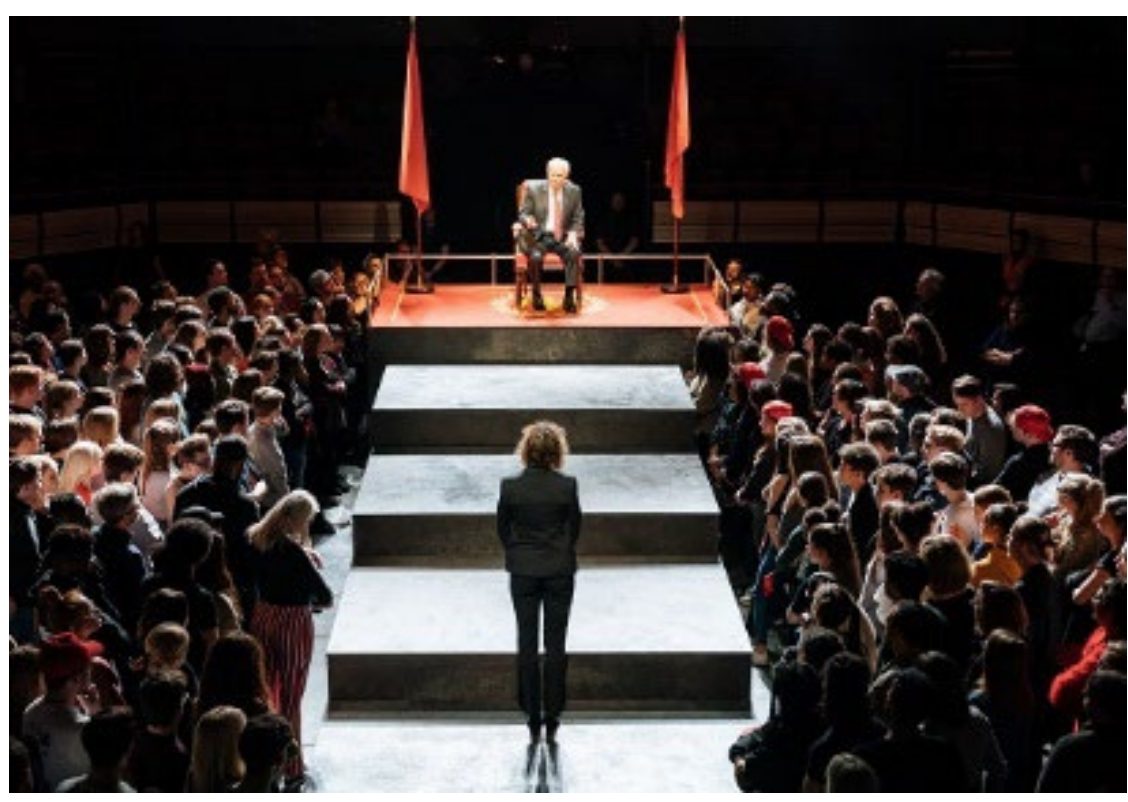

Figure 2. Bunny Christie's set, surrounded by standing playgoers, with David Calder as Julius Caesar and Hannah Stokely as Mellus Cimber. Bridge Theatre. Production, shot by Manuel Harlan. planted in the crowd who appeared to be fellow spectators, became Caesar supporters, Roman citizens, innocent bystanders, and complicit witnesses over the course of the production through flexible, creative, and always effective use of space. I can imagine no other theatre in which a room-sized flag could be draped over the entire playing area and much of the audience before being whisked away; designer Bunny Christie should be commended for crafting such vibrant stage images. 


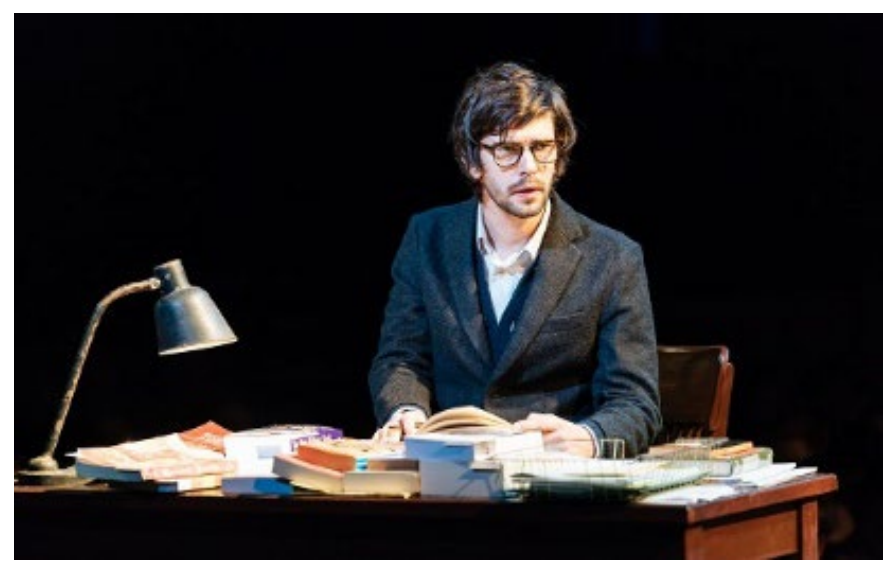

Figure 3. Ben Whishaw as Brutus. Bridge Theatre. Production shot by Manuel Harlan.
And yet the technologically sophisticated playing space never overwhelmed the thoughtful performances on display. Ben Wishaw portrayed Brutus as an aristocratic intellectual, clearly disturbed by Julius Caesar's populism but slightly aloof from the actions his ideas lead him to take. Costume choices-such as his perfect drab-coloured but high-quality tweed overcoat that would seem right on the frame of most English academicsand set design - with his living room featuring tastefully minimalist Scandinavian furniture and office desk holding piles of books of political philosophy-reinforced this reading of the character. But Wishaw's self-contained enactment of stoicism emerged mostly through the chilly calm that tinged his perfect Oxbridge accented speech whenever Brutus encountered a situation which seemed likely to arouse strong emotion. This performance was so effective in large part because it contrasted strongly with the passions displayed by almost every other major character in the play.

Both the opening rock concert celebrating Caesar (David Calder) and his first entrance-wearing one of those Trumpian red baseball caps-created a sense of Caesar's Rome as masculine, adolescent, and coarse. Antony (David Morrissey), whose bulky physicality evoked the power of a professional wrestler, seemed well-suited to this world as he traded banter with Caesar about Calpurnia. One could immediately understand why the cerebral, principled Brutus would find intolerable the prospect of his homeland being subject to the absolute power of such selfimportant frat boys. And casting a number of the major conspirators with female actors-notably Michelle Fairley as Cassius, Adjoa Andoh as Casca, and Hannah Stokely as Cimber-seemed to multiply the reasons for seeing Caesar as problematic. Rather than being an example of genderblind casting, these women's

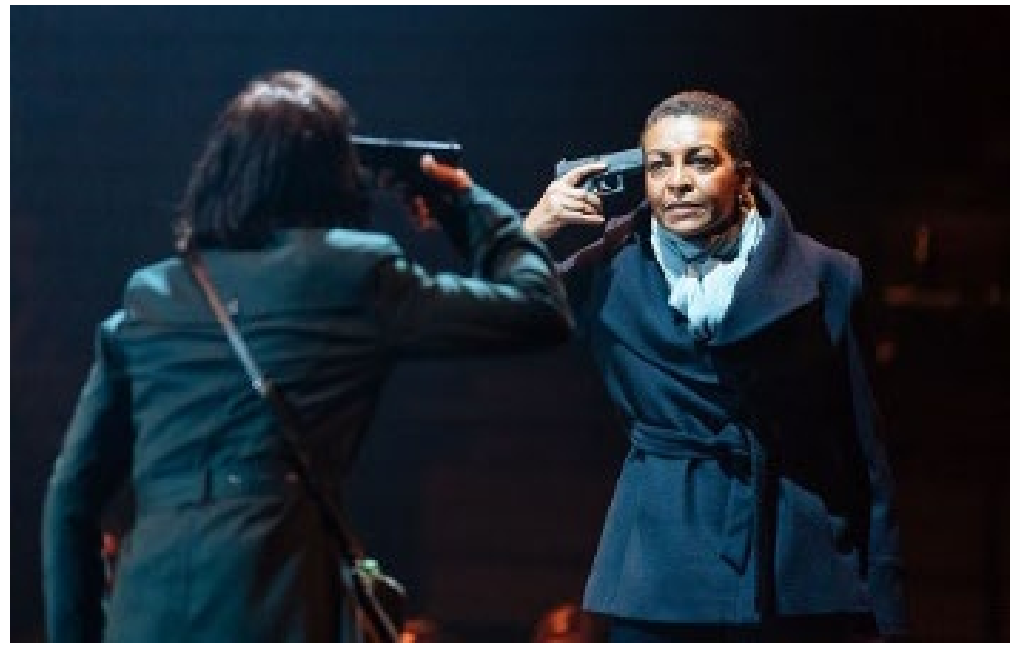

Figure 4. Leaphia Darko as Portia, with Michelle Fairley as Cassius. Bridge Theatre. Production shot by Manuel Harlan. 
performances brought attention to additional nuances of how power operated within Caesar's Rome. Why should these eloquent, chicly dressed, and hyper-professional women strive to give Caesar absolute authority when he seemed so disrespectful to his insightful wife and so attracted to Antony's manly bluster?

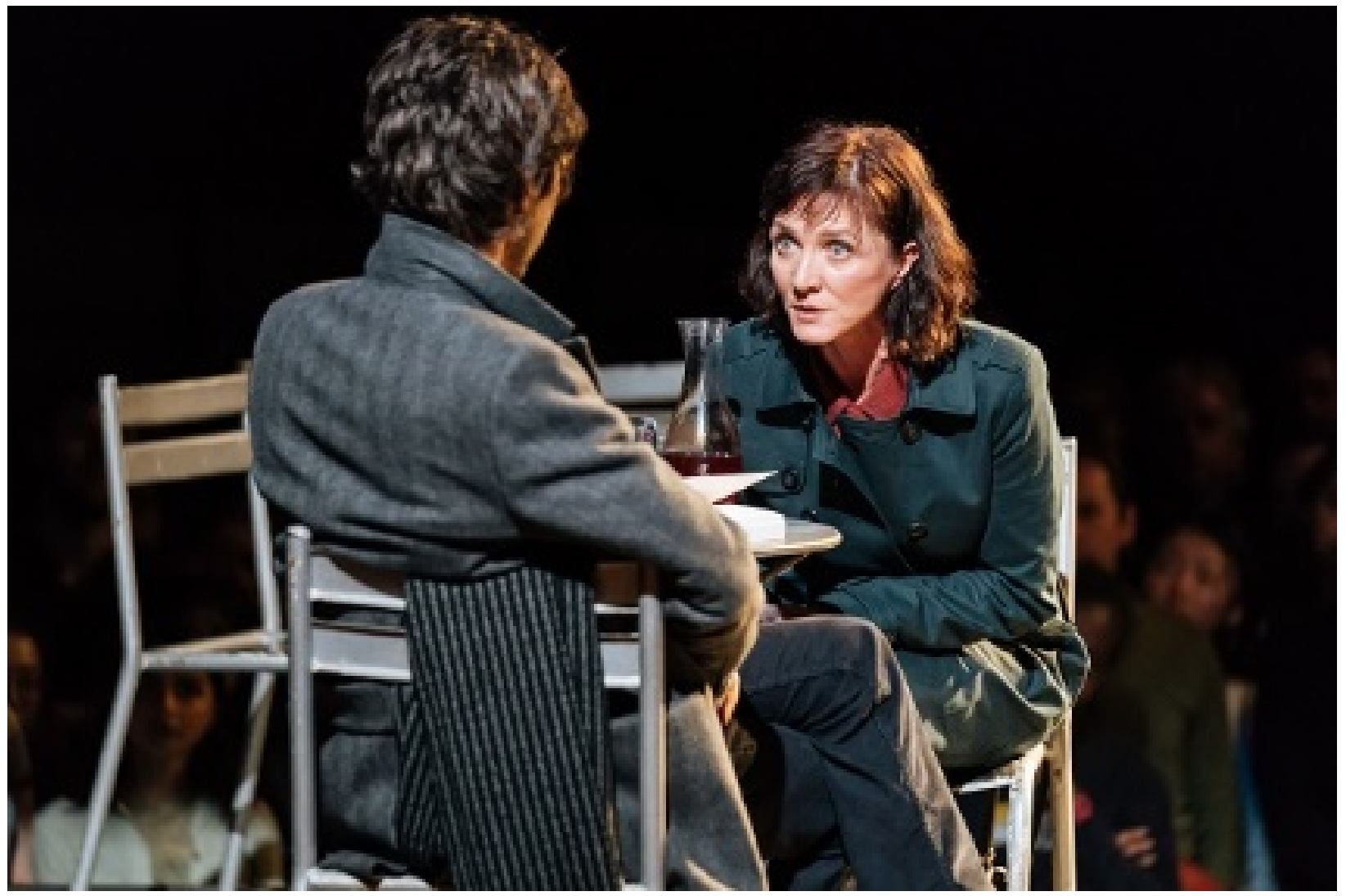

Figure 5. Michelle Fairley as Cassius, with Ben Wishaw as Brutus. Bridge Theatre. Production shot by Manuel Harlan.

Any potential problems that might have been created with these casting choices were turned into opportunities for fresh and often intriguing ways of understanding characters. If women can be professionals and politicians in Rome, why should Portia not be a more active conspirator? Turning Portia (as portrayed by Leaphia Darko) into an invalid struggling with mental illness not only accounted for Brutus's reluctance to tell his wife of his plans but also made her self-inflicted wound and eventual suicide disturbing manifestations of her suffering rather than conventional manifestations of stoicism. Similarly, having Cassius appear as a woman makes all of that character's language about being emotional into a kind of self-deprecating appropriation of sexist stereotypes. Indisputably, Fairley's Cassius seemed as strong in her convictions as Wishaw's Brutus was in his, with the former more prone to express anger, frustration, affection, and fear. 
This production included so many highly effective staging choices that one cannot describe all of them in detail, but a telling example centered around the representation of the assassination. Rather than having Caesar fall to the ground, this Caesar's last moments had him bleeding out from multiple gunshot wounds while slumped in a chair placed in the centre of a platform at the top of a flight of stairs. Not just an unusual blocking choice, this bit of direction created surprising resonances throughout the text. For the first time, I could see the bleeding Caesar as the statue Calpurnia saw in her dream. The conspirators washing their hands in Caesar's blood found themselves having to approach him from below, thus suggesting that they had not completely eliminated his power by murdering him. Grouping all of the conspirators on a lower platform put on display their varied reactions-one dancing with excitement, one standing in shocked silence, and another sobbing hysterically-and suggested why the assassination would not lead to a coherent new republican government. And, most strikingly, all of Antony's language in his funeral oration about Caesar being stabbed and falling-not at all what the audience in the theatre had just witnessed-became more obviously a highly wrought rhetorical performance designed to rile up the crowd (and thus evidence of Antony's populist political acumen) instead of a spontaneous outpouring of emotion.

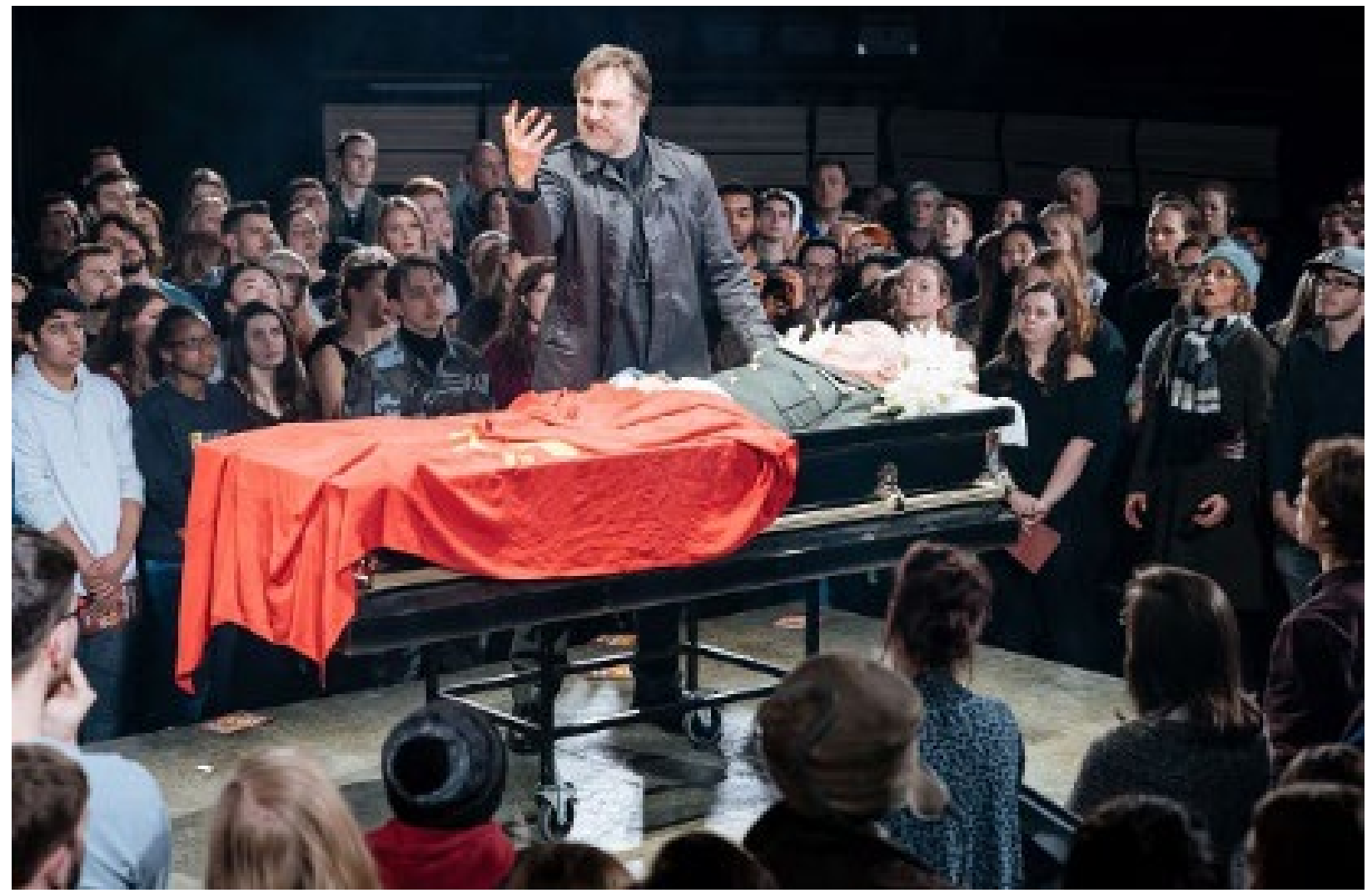

Figure 6. David Morrissey as Mark Antony. Bridge Theatre. Production shot by Manuel Harlan. 
Julius Caesar might have been an oppressive, perhaps even despotic, leader, but this production associated his reign visually with the clean geometric lines of black stairs and platforms punctuated with red hats, flags, and signs. Once Caesar was reduced to a body in a coffin, covered with a red drape, ugly ground-level conflicts began to break out. As soon as the civil war got underway, the entire stage was covered with the sort of debris one associates with bombed out buildings. Visually, it became apparent long before the strategic Antony and the upright Octavius (Kit Young) offered their final speeches that by attempting to eradicate a world that looked big and dumb the conspirators had turned their world into a ruin. Finishing with no easy sense of what it would mean to have good government or ethically effective revolution, this production highlighted the most disturbing aspects of Julius Caesar. Rather than offering localized commentary on Donald Trump's presidency or any other political moment, this complex interrogation of political power was a production for the ages.

It is my hope that this account makes clear how much I admire Nicholas Hytner's direction, Bunny Christie's production design, and all of the actors' performances. Nevertheless, I left the theatre troubled by moments when the play edged over the line from being dangerous in the feelings and ideas it aroused to being (at least potentially) dangerous to the well-being of some audience members. A small sign posted outside one of the performance-space entrances read "The performance of Julius Caesar contains loud sounds, haze, smoke, lasers and strobe lighting," and all of those elements were present - as they might be in a production of Miss Saigon. This sign seemed insufficient, however, to prepare those who would be standing on the ground to be forcefully moved from one spot to another as platforms rose and lowered or as processions moved through the space. It certainly did not warn that some spectators would be inches away as guards brutally beat and kicked the poet Cinna. And it fails to mention that the final scenes of the play would put the standing audience in the midst of a war zone where dust and chunks of tile fell from the ceiling and numerous suicides by self-inflicted gunshot left ears ringing and nerves frazzled.

My own choice to purchase a seat (for $£ 90$ ) rather than to stand (for $£ 15$ ) was swayed by information provided by Andy Kesson's thoughtful meditation on how this production treated its audience and by the advice of friends who saw the National Theatre Live broadcast. But what of those who attended previews or opening week performances? Would they have been adequately prepared for a production that was physically unaccommodating of the small, the weak, and those with limited mobility, not to mention potentially psychologically damaging to anyone with post-traumatic stress disorder? Even though I saw the show very late in the run, I noticed a couple of women-one using a walker-being escorted from the floor by a staff member as the battlescarred landscape emerged. I hope that those audience members were well taken care of, offered 
seats or at least given a complimentary cup of tea in the lobby along with a chance to watch the video feed of the production's ending. My concern that for some present this performance experience wasn't just powerfully disturbing but actually damaging leaves me unable to think of the Bridge Theatre's Julius Caesar as an unmitigated triumph. In an interview made available on the Bridge Theatre's website and on YouTube, Hytner said that his staging was shaped by the notion that the theatre's configuration meant "You can participate, or you can watch," and I was impressed by how this production encouraged all audience members to participate in its consideration of difficult questions about how a leader can and should deploy power. As such, I find troubling the implication that only those who were willing to stand and thus function as part of the crowd were able to participate while those in seats could merely watch. And I hope that all who were on the ground on the afternoon I saw this production felt as positive about their participation as I did.

\section{References}

Kesson, Andy. "I do fear the people': Theatre and the Problem with Audiences." Before

Shakespeare: The Beginnings of London Commercial Theatre, 1565-1595. February 16, 2018.

https://beforeshakespeare.com/2018/02/16/julius-caesar-and-the-politics-of-having-an-

audience/.

\section{Links}

Bridge Theatre. https://bridgetheatre.co.uk/ 


\section{Production Details}

\section{General}

$\begin{array}{ll}\text { Title } & \text { Julius Caesar } \\ \text { Year } & 2018 \\ \text { Theatre Company } & \text { Bridge Theatre } \\ \text { Theatre } & \text { Bridge Theatre Auditorium } \\ \text { Start Date } & 2018-01-30 \\ \text { End Date } & 2018-04-15\end{array}$

Cast

CASCA
JULIUS CAESAR
PORTIA
MARULLUS/ARTEMIDOR
CAIUS CASSIUS
DECIUS BRUTUS
LUCIUS/CINNA THE POET/STREET BAND
PHILO/CLAUDIUS/STREET BAND
CALPURNIA/VARRO
MARK ANTONY
LEPIDUS/CAIUS/LIGARIUS/SOOTHSAYER
TREBONIUS/STREET BAND
FAVIUS/PIPILIUS LENA
CINNA
METELLUS CIMBER
MARCUS BRUTUS
OCTAVIUS/STREET BAND

ADJOA ANDOH

DAVID CALDER

LEAPHIA DARKO

ROSIE EDE

Michelle FAirley

LEILA FARZAD

FRED FERGUS

ZACHARY HART

WENDY KWEH

DAVID MORRISSEY

MARK PENFOLD

ABRAHAM POPOOLA

SID SAGAR

NICK SAMPSON

HANNAH STOKELY

BEN WHISHAW

KIT YoUNG

\section{Creatives}

Director
Production DEsign
COSTUME DESIGN
LIGHTING DESIGN
SOUND DESIGN
COMPOSER
PRODUCTION DRAMATURG
FIGHT DiRECTOR

NICHOLAS NYTNER

BunNy CHRISTIE

CHRISTINA CUNNINGHAM

BRUNO POET

Paul ARditTi

NICK POWELL

AMRITA RAMANAN

Kate WATERS 